\title{
Lessons from Port Sector Regulatory Reforms in Denmark An Analysis of Port Governance and Institutional Structure Outcomes
}

\author{
Merkel, Axel; Sløk-Madsen, Stefan Kirkegaard
}

Document Version

Accepted author manuscript

Published in:

Transport Policy

DOI:

10.1016/j.tranpol.2019.03.010

Publication date:

2019

\section{License \\ CC BY-NC-ND}

Citation for published version (APA):

Merkel, A., \& Sløk-Madsen, S. K. (2019). Lessons from Port Sector Regulatory Reforms in Denmark: An Analysis of Port Governance and Institutional Structure Outcomes. Transport Policy, 78, 31-41.

https://doi.org/10.1016/j.tranpol.2019.03.010

Link to publication in CBS Research Portal

\section{General rights}

Copyright and moral rights for the publications made accessible in the public portal are retained by the authors and/or other copyright owners and it is a condition of accessing publications that users recognise and abide by the legal requirements associated with these rights.

Take down policy

If you believe that this document breaches copyright please contact us (research.lib@cbs.dk) providing details, and we will remove access to the work immediately and investigate your claim. 


\section{Lessons from Port Sector Regulatory Reforms in Denmark: An Analysis of Port Governance and Institutional Structure Outcomes}

\section{Axel Merkel, Stefan Kirkegaard Sløk-Madsen}

Journal article (Accepted manuscript* ${ }^{\star}$

\section{Please cite this article as:}

Regulatory Reforms in Denmark: An Analysis of Port Governance and Institutional

Structure Outcomes. Transport Policy, 78, 31-41.

https://doi.org/10.1016/j.tranpol.2019.03.010

DOI: 10.1016/10.1016/j.tranpol.2019.03.010

* This version of the article has been accepted for publication and undergone full peer review but has not been through the copyediting, typesetting, pagination and proofreading process, which may lead to differences between this version and the publisher's final version AKA Version of Record.

Uploaded to CBS Research Portal: March २०२०

(C) 2019. This manuscript version is made available under the CC-BY-NC-ND 4.0 license http://creativecommons.org/licenses/by-nc-nd/4.0/ 


\section{Accepted Manuscript}

Lessons from port sector regulatory reforms in Denmark: An analysis of port governance and institutional structure outcomes

Axel Merkel, Stefan Kirkegaard Sløk-Madsen

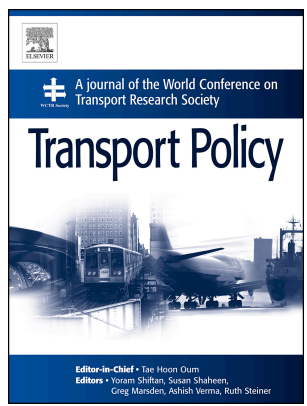

PII:

S0967-070X(18)30374-3

DOI: https://doi.org/10.1016/j.tranpol.2019.03.010

Reference: JTRP 2158

To appear in: Transport Policy

Received Date: 4 May 2018

Revised Date: 19 March 2019

Accepted Date: 25 March 2019

Please cite this article as: Merkel, A., Sløk-Madsen, S.K., Lessons from port sector regulatory reforms in Denmark: An analysis of port governance and institutional structure outcomes, Transport Policy (2019), doi: https://doi.org/10.1016/j.tranpol.2019.03.010.

This is a PDF file of an unedited manuscript that has been accepted for publication. As a service to our customers we are providing this early version of the manuscript. The manuscript will undergo copyediting, typesetting, and review of the resulting proof before it is published in its final form. Please note that during the production process errors may be discovered which could affect the content, and all legal disclaimers that apply to the journal pertain. 


\title{
Lessons from port sector regulatory reforms in Denmark: An analysis of port governance and institutional structure outcomes
}

\author{
Axel Merkel
}

Faculty of Logistics, Molde University College - Specialized University in Logistics

Molde University College PO Box 2110, NO-6402 Molde, Norway, axel.p.merkel@ himolde.no, +47

71214262

Stefan Kirkegaard Sløk-Madsen (Corresponding author)

Department of Innovation and Organizational Economics, CBS Maritime, Copenhagen Business School

Kilevej 14, 2000 Frederiksberg, Denmark, Sks.ino@ cbs.dk, +45 38154248

This paper studies the recent regulatory reform and current institutional structure of the Danish port sector. We document changes with regard to the structure of management, the financial strength and the market power of partially or fully municipally controlled ports in response to the Port Law passed in 1999 and most recently revised in 2012. This law enabled greater degrees of freedom for ports to engage in cargo handling operations while in some cases retaining advantageous public financing. During a period of overall slowdown in goods volumes, we document expansionary development of municipally controlled ports, and we argue that such a phenomenon is attributable to the institutional structure and rules set by the Danish Port Law. For a future legal framework to successfully aid the port sector in realizing its relevant goal of cost-efficiently producing goods handling services, the risk of opportunistic behavior needs to be explicitly recognized and managed.

Keywords: Port governance; Intra-port competition, Port policy, Public choice, PublicPrivate competition

Acknowledgements: No financial grants or other funding has been awarded for this research. The authors have no conflicts of interest to declare. 


\section{Lessons from port sector regulatory reforms in Denmark: An analysis of port governance and institutional structure outcomes}

This paper studies the recent regulatory reform and current institutional structure of the Danish port sector. We document changes with regard to the structure of management, the financial strength and the market power of partially or fully municipally controlled ports in response to the Port Law passed in 1999 and most recently revised in 2012. This law enabled greater degrees of freedom for ports to engage in cargo handling operations while in some cases retaining advantageous public financing. During a period of overall slowdown in goods volumes, we document expansionary development of municipally controlled ports, and we argue that such a phenomenon is attributable to the institutional structure and rules set by the Danish Port Law. For a future legal framework to successfully aid the port sector in realizing its relevant goal of cost-efficiently producing goods handling services, the risk of opportunistic behaviour needs to be explicitly recognized and managed.

Keywords: Port governance; Intra-port competition; Port policy, Public choice, Public-Private competition

Acknowledgements: No financial grants or other funding has been awarded for this research. The authors have no conflicts of interest to declare.

\section{Introduction}

The question of how to organize and finance public works is at least as old as the study of political economy. Smith ([1776] 1976) famously distinguished between the types of public work that can be financed by the users of the facilities and those that cannot afford enough revenue to cover maintenance. The latter, Smith argued, are best maintained under local administration and with local revenue, rather than financed by the general public. Such public works were made to support commerce, where commerce could support them, and their 'grandeur and magnificence' were scaled to the needs of commerce. The modern academic and political discussion on infrastructure policy bears resemblance to these origins, in that it often centres on questions of 
user vs. taxpayer financing, and what tier of government, if any, should be in charge (e.g. Estache and Fay, 2007). Maritime port governance constitutes a complex regulatory task as ports, which facilitate the flow of countries' international trade, are typically endowed with some level of market power due to their unique location. As a way of preventing the exploitation of such market power, it is often the case that port operators are subject to public control or exposed to competition, e.g. through concession policies. This paper examines a contemporary example of such regulatory practices in a Nordic-model mixed economy. We present the case of port governance in Denmark anno 2017.

Denmark along with its fellow Nordic neighbours is heavily reliant on foreign trade carried by sea. In Denmark, which has a population of roughly 5.7 million, there are 60 maritime ports publicly open to international traffic (Eurostat 2018a). This figure is comparable to that of Sweden, which has a population of roughly 10 million, and 54 publicly open ports (Eurostat 2018a). Figure 1 illustrates the similar levels and trajectories in goods volumes handled in the Nordics during the past two decades. The policy regulating port activities in Denmark has seen a long-term shift from a system with significant degrees of centralized coordination to a system in which much control lies within local governmental units. The formal rules governing port activities and organizations changed discontinuously when a new policy package (the Port Law) was passed in 1999. The intention of this law was to allow public ports to be developed commercially, while facilitating fair competition between public and private service providers. In light of much public discussion concerning the functioning and efficacy of this law, this paper is dedicated to studying policy-relevant outcomes. Specifically, we aim to find whether ports have in fact been commercialized in terms of management, and whether there is evidence that the current institutional framework has provided a basis for fair competition in ports. The purpose of the paper is twofold: to provide a review of the unique Danish legal port governance framework, 
as well as to assess its success in facilitating intra-port competition. The first part of this purpose is achieved by describing the rather dense legal framework that constitutes port policy in Denmark, including changes over time, and highlighting the incentive structure embedded in this framework. The second part of the purpose is achieved by analysing policy-relevant outcomes of the reform process, including changes in tariff revenues per ton of cargo handled, changes in port assets and equity as well as the remuneration of port CEOs. The overarching research question of the paper is whether and to what extent the institutional framework in place has influenced the market power of Danish ports. Given the complexity of the question, we find it appropriate to first provide a contextual background of the Danish port system and then analyse a variety of indicators in order to conclude based on a comprehensive set of facts.

The paper proceeds with a review of port governance reform in the academic literature, as well as the study of economic rent in ports. Section 3 presents the current legal framework governing ports in Denmark. Section 4 outlines methodological choices and section 5 presents our findings. Section 6 is devoted to a critical discussion on matters pertaining to policy and section 7 summarizes our conclusions.

Figure 1 - Development of goods volumes in Nordic ports

[Fig 1 here]

Source: Eurostat (2018b)

\section{Port governance: decentralization, devolution and the role of port authorities}

Port governance is a term generally used to refer to the issues of ownership, pricing, investment, as well as the division of responsibilities and liberties among different actors in maritime ports. A modern discussion regarding normative issues such as how responsibilities 
should be divided among different port actors began with Goss (1990a, 1990c). Goss emphasized among other things that the role of ports ought to be to minimize the generalized cost of transport and that a desirable role for a public sector port authority is to provide services which can be classed as public goods, while facilitating competition between private operators to efficiently supply other services. The same strand of work (Goss, 1990b) also set out to describe extreme or archetypal instances of port governance systems, such as the 'comprehensive' port, in which a port authority is responsible for everything, including the provision and maintenance of infrastructure, superstructure and performing goods handling operations and services to ships. On the other extreme end, a 'landlord' port can be envisaged, where the authority is only engaged in leasing out land to private terminal operating companies. This framework heavily influenced much subsequent literature, including the World Bank Port Reform Toolkit (WBPRT), which sets out to support institutional reform in (developing) countries' maritime port sectors (World Bank, 2007). The document sketches four models of ports with regard to characteristics related to ownership, geographical orientation, public/private service provision and labour status. The four models are the service port, the tool port, the landlord port and the fully privatized port. The service and landlord ports are largely similar to the comprehensive and landlord port sketched above, while the tool port is one where the port authority has ownership and control of infra- and superstructure and owns and operates the cargo handling equipment. Other cargo handling activities in the tool port are handled by private firms, which means that the operational responsibilities are split between private firms and the port authority, marking a major distinction from the landlord model. Such an organization reduces the capital investments (and risk-taking) required by a private cargo handling firm, but it also deprives such firms of achieving scale economies and developing strong balance sheets. The fully privatized port is a significant step beyond the landlord model, where, following a transfer of ownership (and sometimes regulatory 
responsibilities) from public to private, every factor of port service production is under private control.

Port governance models such as the WBPRT generally describe how transaction costs can be economized on by getting the right rules in place, including dividing responsibilities and rights of the public and private sector and facilitating fair competition in the provision of port services. In the study of ports, less attention has been paid to how such rules are actually enforced, as well as how actors respond to formal rules. It has been argued that the generic port governance solutions provided by e.g. the WBPRT combined with the highly distinctive and diverse institutional frameworks already in place has led to asymmetric implementation of similarly intended reforms ( $\mathrm{Ng}$ and Pallis, 2013). The issue of implementation of a generic framework in countries and ports with heterogeneous traditions is also emphasized by Pallis (2006). In a similar vein, the concept of institutional plasticity, the stretching and reshaping of institutional arrangements to fit a particular purpose, has been used as a way to understand port development (Notteboom et al., 2013).

\subsection{Institutional reforms}

Facing changes in the economic environment in which ports operate, governance reforms have been undertaken in many countries (other than Denmark), with notable cases including the UK, France, Italy, Greece and Canada, and several others. The first wave of port governance reforms in the 1990s displayed many similarities between countries (Brooks and Cullinane, 2017). These reforms, though diverse in their outcomes, mostly had in common that the objectives were to devolve (i.e. transfer) managerial responsibilities to private actors or lower tier public sector bodies, and to commercialize port service provision by transforming public to corporate port entities with more autonomy (Brooks and Pallis, 2012). Brooks (2004) and Baird (2000) 
described and categorized the range of outcomes (in terms of division of responsibility between public and private actors) of port reforms in different countries, and noted that there is a variety of ways to commercialize port activities without full privatization. After this first wave of reforms, there have been more recent reforms or adjustments to laws concerning port management that have not been as uniform with regard to intended outcomes. In some cases, such as the latest reform in Italy, there have even been tendencies toward re-centralization of governance (Parola et al., 2017). In Italy, an initial reform implemented in 1994 staked out a clear role for port authorities, which included landlord duties, as well as some policy and planning functions but prohibited the port authority from performing operations (Valleri et al., 2006). The reform triggered a shift toward private capital and investments in Italian ports, leading to a situation in the late 1990s where the market share of Italian ports' peaked. Subsequent reforms included increasing the number of port authorities by upgrading the status of local port administration and a recent reform in 2016 reversed this increase and reorganized port authorities into only 15 strategically based units (Parola et al., 2017). The policy in place is described by Parola et al. (2017) as having led to an overly complicated institutional structure with weakened local influence and a less flexible (or 'plastic') framework to adapt to local needs. In France, a law in 2004 transferred ownership and management responsibilities in 17 ports to local authorities (Debrie et al., 2007), creating more diversity in port management. A subsequent reform in 2008 was applied to France's main ports by modifying their status, privatizing operations and allowing the transfer of public assets in ports to private operating companies (Debrie et al., 2017). Outcomes of the reforms have been influenced largely by regional factors (Debrie et al., 2013). In Greece, a first wave of reform began in 1999 and a second started in 2008 (Pallis and Vaggelas, 2017). In line with the trend of devolution, the first period of reform in the Greek port sector was intended to increase the autonomy and to commercialize the 
operations of ports, transitioning from a governance model of state-controlled comprehensive ports (Pallis, 2007). The most recent reform introduced a new model of governance with terminal concessions. Though outcomes in the Greek case have been difficult to predict due to limited time for observation, since political and economic crises prolonged the reform period, documented effects include increased market concentration in the container segment (Pallis and Vaggelas, 2017). Spain has undergone six legal reforms (in 1992, 1997, 2003, 2010, 2011 and 2014) with diverse purposes and policy tools (Castillo-Manzano et al., 2018). Initially, the reforms aimed at transitioning the governance models from service to landlord, improving coordination of the port system and allowing ports' an increased level of autonomy under certain criteria. Subsequent reforms have aimed toward improving inter-port competition, liberalizing the provision of port services and promoting private investment (Castillo-Manzano et al., 2018; Gonzales and Trujillo, 2008). Several of these reforms are found to have positively influenced competition. Interestingly, it is found that the most effective reforms were those that were backed by broad political and industry support. In the UK, port reform was largely a reform in ownership, where a privatization process began in the 1980s, coupled with deregulation of manning rules for dockworkers (Baird and Valentine, 2006). The reform has been described as unusual in the sense that transfer of essentially all port functions, including regulatory duties, to the private sector is unique. This privatized state of the UK port system naturally means that there is less scope for public policy or reform, but there are still issues of governance to be dealt with, such as making sure stakeholders in the port sector have the means to achieve good outcomes for the economy (Monios, 2017b). 


\subsection{The issue of market power and economic rent}

The supply of maritime infrastructure (harbors, locks, fairways) can be described as fully inelastic, at least in the short run. An implication of this fact is that these resources are susceptible to opportunistic or so-called rent-seeking behavior, where those in possession or who exercise some degree of control over the resources seek to make private gains, while at the same time incurring a loss of welfare on society (e.g. Krueger, 1974). Rents in seaports extracted by owners, operators, or infrastructure providers are characterized by Goss (1999) as non-reductions in the generalized cost of transport, which are possible only in the (usual) case where inter-port competition is imperfect, i.e. there is a substantial differential in generalized cost of using the port and re-routing according to the second-best alternative. With such a differential, the port enjoys some level of market power. This argument is reviewed and discussed by De Langen and Pallis (2006), who examine the conditions under which actors may end up with market power to the extent that rent extraction is possible. An important point made is that facilitating intra-port competition can prevent rent extraction made possible by imperfect inter-port competition, but there are a variety of conditions under which intra-port competition is not necessary for this purpose, such as when hinterland markets are contestable. The contestability of port markets are affected by the ease of entry and exit, which is an issue analysed by De Langen and Pallis (2007). It is found that entry barriers can be cumbersome, and that there is a role for policy in reducing such barriers e.g. through efficient concession structures. In an analysis of the Portuguese regulatory framework for ports, Marques and Fonseca (2010) note that such regulations are crucial to prevent the abuse of market power in the sector. A recent study examining port competition policy in Latin America and the Caribbean (Suarez-Aleman et al., 2018) emphasizes that policy-making for securing competition in ports consists not only of getting the right rules in place, but also of monitoring and preserving competition in the market. In a game-theoretic 
analysis of different models of port organization, van Reeven (2010) finds that the introduction of intra-port competition in landlord ports can reduce excess profits and lead to lower prices for customers. Perhaps more importantly, it is found that such solutions are not incentivized without proper regulatory enforcements. Overall, the literature emphasizes that active policy measures are needed to prevent market failures relating to insufficient competition in port service provision.

\section{Rules of the game: a review of Danish port policy}

Prior to the passing of the Danish Port Law (Havneloven, own translation) in 1999, Danish ports were regulated by an older piece of legislature called the Commercial Ports Law (Trafikhavneloven, own translation). This law was originally created in 1976 and it stipulated that service fees, commodity-specific handling charges and port investments be regulated by the central government (Ministry of Transport and Energy, 2007). In 1990, the law was amended and the centralized pricing and investment scheme was removed. The intention of this amendment was to de-bureaucratize port management and promote competition between ports. Continued efforts to commercialize ports resulted in the adoption of the Port Law in 1999. Under this law, which was subsequently amended in 2003, 2005, 2007 and 2012, ports were given the opportunity to choose organizational form. The intention of this reform was to allow ports differentiated degrees of freedom in carrying out business activities, where more freedom would be given to ports whose organizational structure permitted more independence from their public owners. The law allowed ports to be organized according to one of the following five classifications: state port, municipal port, municipal self-governed port, fully or partially municipally owned limited company or privately organized port. Out of the 60 publicly open ports mentioned in the introduction, 20 of these are organized as municipal 30 as municipal self- 
governed, and 10 as fully or partially municipally owned limited companies. In addition, there are around 30 examples of privately organized ports (Ministry of Transport and Energy, 2007).

The two principally important forms of organization in the Port Law are the municipally selfgoverned (henceforth MSG) ports and fully or partially municipally owned limited company (henceforth MOLC) ports. They are important in the sense that most large and important Danish ports are organized as either of these. MSG ports differ from municipal ports in that they are managed by a separate port board, appointed by the municipal council. The port is run independently from the municipality, in that day-to-day management and accounts are kept separate. Like municipal ports, MSG ports can provide and manage infrastructure, as well as supply operators with cranes, warehouses and other equipment. MSG ports are not ordinarily allowed to perform port-related or ship-related services, but under special circumstances where no private actor has been identified to take on these tasks, this is allowed. Prior to the 2012 amendment of the Port Law, the circumstances under which MSG ports could perform such operations were differently specified. Before the amendment, special permission from the ministry was required. Under the current law, no such permission is required. The law does however require that the port attempts to identify a private actor (and does not succeed in doing so) prior to performing operations itself. The amendment was preceded by a report by a selected committee of experts (Havnelovudvalget, 2011). The committee recommended that due to the complex nature and rapid changes in the transport sector, ports needed to be given a more flexible framework in order to meet the competition from ports in other countries. A MOLC port, by contrast, is a business enterprise. Ports organized in this way have the same liberties as MSG ports, but can also unconditionally engage in port-related operations. Under special circumstances where no private actors can be identified, MOLC ports can also perform ship-related operations. The similarities and differences in what ports organized as either MSG or MOLC are allowed and 
restricted to do, as stipulated by the latest version of the Port law (LBKG $\mathrm{nr}$ 457), are summarized in table 1.

In transitioning to the Port Law, certain Danish ports were given a special exemption to keep operational rights that would not otherwise be available to them in their organizational structure (Ministry of Transport and Energy, 2007). These were termed "grandfather rights". This meant for instance that the Port of Grenaa could unconditionally retain its right to perform towing services, even though it was organized as MOLC. Such rights were also given to some MSG ports, such as the Port of Vejle, which was also permitted to operate towing services, or to Aarhus, which was unconditionally permitted to perform pilotage, towage and line handling services.

In terms of the archetypal governance structures described in section 2, MSG and MOLC ports can be described as hybrids of the 'landlord' and 'tool' models. MSG ports could technically be regarded as landlord ports, with the additional option of providing operational services when there is insufficient private competition. MOLC ports are closer in fashion to the tool port model, as they are unconditionally allowed to perform port-related services. In MOLC ports, operational responsibilities are thus always split between the port and private service providers, as there is no regulation prohibiting competition between the port and external providers of the port-related operational (e.g. cargo handling) services. By contrast, the MSG port structure is designed not to induce competition between public and private services, only to 'fill in the gaps' in the range of services offered by external providers. One of the points of having a range of organizational structures with differentiated degrees of operational freedom available to ports is that MSG ports can in principle only expand their business to compete with private operators if they opt to shift to the MOLC organizational form. Such a transition can be done following a decision by the municipal council, and is not regulated in the Port Law. While it was hypothesized that the Port 
Law would incentivize and induce commercially oriented MSG ports to become MOLC ports, very few have utilized this option. Several possible strategic reasons for MSG ports not to opt for the MOLC structure have been identified (Ministry of Transport and Energy, 2007). One such reason is that municipalities may be hesitant to give up control of land areas in or around the port. If the municipality in such a transfer partially gives up ownership (immediately or in the future), it may find it more difficult to invest in e.g. residential housing on such areas. Another reason why MSG ports may hesitate to shift is that while MSG ports have privileged access to funds under the Danish municipal borrowing order (Kommunale lånebekendtgørelse, own translation), MOLC ports will have to be financed on commercial borrowing terms. ${ }^{1}$ Furthermore, $\mathrm{MSG}$ ports are - being part of municipalities - exempt from corporate taxation, while MOLC ports are liable to pay corporate tax as any other privately held company.

\footnotetext{
${ }^{1}$ Such financing is done via KommuneKredit, which is a membership borrowing association of Danish municipalities and Regions whose members are directly jointly and severally liable for all of the associations' obligations. As security for the loans is the unlimited right of municipalities to levy taxes on income and property. The access to relatively cheap financing provided by the association rests in part on the total asset size. Financing port expenditure is often many times more expensive than many smaller financing needs of municipalities, hence removing port financing from KommuneKredit would theoretically make all below federal level public financing more expensive. It is beyond the scope of this paper to comment on the complex cost-benefit analysis of such a situation.
} 
Table 1: Legally allowed functions and restrictions of MSG and MOLC ports under the Port law

\begin{tabular}{lcc} 
Allowed functions/Responsibilities & MSG & MOLC \\
\hline Can manage and operate infrastructure including quay and harbor basins & $\mathrm{X}$ & $\mathrm{X}$ \\
\hline Can lease land and buildings to private companies & $\mathrm{X}$ & $\mathrm{X}$ \\
\hline Can enter into cooperative agreements with other ports & $\mathrm{X}$ & $\mathrm{X}$ \\
\hline Can provide cranes and warehouses to service ships, stevedores and others & $\mathrm{X}$ & $\mathrm{X}$ \\
\hline Can perform port-related operations (e.g. stevedoring, warehousing) & $\mathrm{X}^{\dagger}$ & $\mathrm{X}$ \\
\hline Can perform ship-related services (e.g. towage, pilotage) & $\mathrm{X}^{\dagger}$ & $\mathrm{X}^{\dagger}$ \\
\hline Can use excess capacity to sell services & $\mathrm{X}^{\dagger}$ & $\mathrm{X}^{\dagger}$ \\
\hline Can own and operate buildings and facilities that serve the port user & $\mathrm{X}^{\dagger}$ & $\mathrm{X}^{\dagger}$ \\
\hline Can own and operate hydro and wind power plants & $\mathrm{X}^{\dagger}$ & $\mathrm{X}^{\dagger}$ \\
\hline Can provide other services intended to support port users & & $\mathrm{X}^{\dagger}$ \\
\hline Can invest up to 15\% of the company's equity in foreign ports. & & $\mathrm{X}$ \\
\hline Must cover costs & $\mathrm{X}^{\dagger}$ & $\mathrm{X}$ \\
\hline Must keep day-to-day administration separate from that of the municipality & $\mathrm{X}^{\dagger}$ & $\mathrm{X}$ \\
\hline Must account funds separately from those of the municipality & & $\mathrm{X}^{\dagger}$ \\
\hline
\end{tabular}

†Under the condition that the activity is not already undertaken by a private actor, and that no private actor has been identified despite advertisement (the forms of which are regulated by the same law) to perform the activity. The activity must be performed by a separately taxed company operated on market terms.

The terms set out by the Port Law have been subject to dispute as to when port practices can be regarded as encroaching on private service provision. A notable recent case includes Lindø Port of Odense and a private service provider. The service provider accused the port of performing port-related operations that would be prohibited, as the port was MSG (Søndergaard and Kaarøe, 2017). After the Danish Transport, Construction and Housing Authority agreed that the port was indeed engaging in unlawful competition with a private service provider, Lindø Port of Odense opted to shift to an MOLC structure. The Port Law does not specify whether or how violations should be sanctioned. 


\section{Methodological framework}

This paper investigates how the set of formal rules created with the Port Law have affected the functioning of the port system and by extension, whether ports have been able to exert market power due to the institutional framework created. The limitations to the forms under which ports can produce services in competition with private companies, as reviewed in the previous section are not backed by sanctions or penalties. In addition, the latest revision of the law loosened parts of this regulation, such as the requirement that MSG ports would require ministry permission to perform operator services. If commercialized ports operated under business-like conditions were to successfully strengthen their market position in this institutional environment, this is likely to show up in financial and operational measures of performance. This is the hypothesis examined in the remainder of this paper. In order to do this, we first study the long-term change in the competencies of Danish ports from before the first version of the Port Law was passed until 2016, and then analyse their financial statements over a sample period when the regulation has been in effect.

We use the economic-individualist methodology as described in Buchanan \& Tullock (1962). This is based on the assumption that agents seek to maximize their utility to the fullest within the given institutional constraints disregarding if they are employed in the private or public sector. Utilizing an economic-individualist methodology implies that we are not interested in ex-ante motives but ex-post observable outcomes. Consequently, the sources utilized in this paper are publicly available or publicly requestable. Our findings are based solely on such sources. We did as a supplement conduct two rounds of interviews with stakeholders for background information and conceptualization. The first round was done before writing and data gathering, and the second after the first version of the paper was completed. Such an approach was chosen to ensure both independent hypothesis formulation and to check finding validity. Our motivation for 
studying changes in changes in the skills and backgrounds of port management is the concept of distinctive competencies (Learned et. al., 1969, Hrebiniak \& Snow, 1982, Hitt \& Ireland, 1985), meaning that small size organizations, such as ports, get their precise competencies mainly from people, and less so from standard operating procedures. These competencies form a base from which strategies are envisioned and decisions made.

There are two potential problems with studying port accounts for the purpose of testing our hypothesis. The first is that financial measures are not necessarily reflective of the long-term picture in terms of port performance. To alleviate this issue, we use longitudinal data from 2011 to 2016, and we compare the development in revenues to the base of these revenues: goods volumes in the respective ports. The second problem is that, as mentioned previously, economic rent extracted by an owner does not necessarily show up as profits but may rather be reflected in low levels of technical efficiency. This implies that our method is limited to identifying such surpluses as can be measured in accounting terms. By covering a wide base of indicators and supplying appropriate values for comparison or benchmark, we are nevertheless able to provide an understanding of overall observable market outcomes in the Danish port sector. 
Table 2 - Peer Group Members

\begin{tabular}{|c|c|c|}
\hline Port & Type & $\begin{array}{c}\text { Annual } \\
\text { throughput }\end{array}$ \\
\hline Aarhus & MSG & 8142 \\
\hline ADP & MOLC & 10507 \\
\hline CMP & MOLC & $14377^{\dagger}$ \\
\hline Esbjerg & MSG & 4459 \\
\hline Frederikshavn & $\mathrm{MSG}^{\ddagger}$ & 2384 \\
\hline Grenaa & MOLC & 1344 \\
\hline Kalundborg & MSG & 1652 \\
\hline Køge & MSG & 1684 \\
\hline Lind $\varnothing$ port of Odense ${ }^{\S}$ & MOLC ${ }^{\pi}$ & 2050 \\
\hline Vejle & MSG & 787 \\
\hline
\end{tabular}

Note: Annual throughput refers to an average over the sample, measured in thousand tons.

$\dagger$ This includes both the port of Copenhagen and Malmö, as they are jointly operated by CMP.

$\ddagger$ Was MOLC for part of the period.

$\S$ Prior to its purchase of Lindø Industrial Park in 2013, the name was the Port of Odense.

ฯ Changed from MSG in 2017.

The analysis is based on a peer group of Danish ports. The members of the peer group were selected to be representative, containing both the MSG and MOLC ports without bias. The reason for studying only MSG and MOLC ports is firstly that these are the predominant forms of organization for commercially significant ports in Denmark. Secondly, they are the organizational forms whose allowed functions have changed with revisions of the Port Law. The sample ports were randomly selected among ports suggested by first round interview persons. In principle, every MOLC and MSG port could be selected for the purpose of our study. However, due to the time required to obtain and analyze in depth the financial statements and organizational aspects of each port, we have chosen a sample size of 10 ports. Our population of interest is ports affected by regulatory changes, and we are specifically interested in large ports since these are of greater importance to the economy. Seven ports in our sample belong to the ten largest ports in Denmark, and all of the ports are in the top 20 (in tonnage terms). Further, we want to have a significant share of the population of ports organized as both MSG and MOLC. Our four sample ports organized as MOLC represent $86 \%$ of total MOLC tonnage, and our sample of MSG ports 
represents $57 \%$ of total MSG tonnage. Though we cannot fully rule out that there may be some skewness in our chosen sample, the method of selecting units before gathering any data, combined with having a sample that comprises most of the population, greatly reduces the likelihood of large biases. Our peer group is listed in table 2. Figure 2 shows the composition of goods in the sample ports compared with the entire port sector during our years of observation. As can be seen, there is a slight overweight of containerized cargo and a slight underrepresentation of cargo classified as "other", which partly due to the fact that many small ports report relatively large volumes of unspecified cargoes. Overall, the sample does not deviate a large amount from the composition of goods compared to the sector as a whole.

Figure 2 - Share of cargo volumes in sample ports (left-hand panel) and in all Danish ports (right-hand panel) during 2011 - 2016

[Fig 2 here]

Source: Eurostat (2018b).

\section{Analysis of outcomes}

The structure of management and the background of key persons influence organizational behaviour, and are therefore important in studying outcomes of the institutional framework. The original institutional setup contained a checks-and-balances system to limit short-term opportunism or overly commercial behaviour. This was in the form of the Collective Bargaining Agreement governing port personnel (KL, 2016), requiring that the daily manager of the port had to have a maritime (rather than a commercial) background. To test if competencies in fact remained the same, we mapped the background of the CEO, the Chairman and whether they had a Business Development (or similar) department in 1996 and 2016. We find that management and the board level of ports have increasingly become commercially minded and that the control of the port companies by elected politicians diminished as shown in table 3 . The rule of maritime 
background of managers has been bypassed by adding a new commercial management layer on top of the daily operations or by a looser interpretation of the requirement. It is notable that while nine out of ten ports where run by a person with a maritime background prior to the passing of the Port Law, the current figure is two out of ten, the rest being commercial. Similarly, every port in the sample was chaired by an elected politician prior in the pre-regulation period, while the post-regulation figure is four out of ten.

Turning to the financial statements of our peer group from 2011 (the last full financial year before the latest amendment of the law) up to and including 2016, we are interested in revenue, as it tells us if the operations have grown and in profitability indicators: earnings before interest and taxes (EBIT) and return on equity (ROE), as it tells us to what degree port operations are profitable. We study total assets as it tells us if capital investments have increased. We are also interested in equity, as it tells us if the value of ports as stand-alone commercial entities have increased. We will examine these figures using simple percentage growth rates and compounded annual growth rates (CAGR). We compare growth rates in revenue with growth rates of goods (measured in tons) handled in each respective port. A positive difference between the growth rates in revenue and goods volumes indicates either that revenue sources not directly related to throughput (such as leasing, fishing or energy production) have increased, or that ports have expanded operations of throughput-related services at the expense of other service providers. A third possibility could be that ports have increased the price of such services without loss of business to competitors, which is itself an exertion of market power. In table 4, we examine these developments in the sample. Looking at the numbers in Table 4, all ports, both measured in simple growth and CAGR, outperform the general market trend, except Vejle Port and CMP. In other words, revenue growth outperforms volume growth in all but two ports. It is notable that three ports exhibit negative volume growth, while revenues are increasing. For Vejle, which is an 
exception, we note that the negative revenue growth is explained by a large fall from 2011-2012 after which revenue grows by around $4 \%$ over the period. We are so far unable to fully explain the sudden drop in revenues during 2011. In CMP, revenues and volumes have increased at roughly the same rate. Aggregating the sample, we see that revenues have increased by roughly $30 \%$, while volumes have declined by around $10 \%$. A breakdown of the revenue figures into specific components shows that the growth is in tariff revenues (exempting revenue from ferries), land leasing revenues and revenues categorized as stemming from "other" sources. Revenues from tariffs increased on average by $18 \%$, and the only port in the sample exhibiting negative revenue growth from tariffs is Vejle.

Table 3 - Primary Management Background

\begin{tabular}{|c|c|c|c|c|c|c|}
\hline & 1996 & & & 2016 & & \\
\hline $\begin{array}{l}\text { Name and } \\
\text { current } \\
\text { organizational } \\
\text { structure }\end{array}$ & $\begin{array}{l}\text { CEO primary } \\
\text { background. }\end{array}$ & $\begin{array}{l}\text { Business } \\
\text { development } \\
\text { department }\end{array}$ & $\begin{array}{l}\text { Chairman } \\
\text { background }\end{array}$ & $\begin{array}{l}\text { CEO primary } \\
\text { background }\end{array}$ & $\begin{array}{l}\text { Business } \\
\text { development } \\
\text { department: Y / } \\
\mathrm{N}\end{array}$ & $\begin{array}{l}\text { Chairman } \\
\text { background: } \\
\text { Commercial or } \\
\text { political }\end{array}$ \\
\hline Aarhus (MSG) & Maritime & No & Political & Commercial & Yes & Political \\
\hline ADP (MOLC) & Maritime & No & Political & Commercial & Yes & Commercial \\
\hline CMP (MOLC) & Bureaucratic & Yes & Political & Commercial & Yes & Commercial \\
\hline Esbjerg (MSG) & Maritime & Yes & Political & Maritime & Yes & Commercial \\
\hline $\begin{array}{l}\text { Frederikshavn } \\
\text { (MSG) }\end{array}$ & Maritime & No & Political & Commercial & Yes & Commercial \\
\hline Grenaa (MOLC) & Maritime & No & Political & Commercial & Yes & Political \\
\hline $\begin{array}{l}\text { Kalundborg } \\
\text { (MSG) }\end{array}$ & Maritime & & Political & Maritime & No & Political \\
\hline Køge (MSG) & Maritime & No & Political & Commercial & No & Political \\
\hline $\begin{array}{l}\text { Odense } \\
\text { (MOLC) }\end{array}$ & Maritime & No & Political & Commercial & Yes & Commercial \\
\hline Vejle (MSG) & Maritime & No & Political & Commercial & No & Commercial \\
\hline
\end{tabular}

Source: Port webpages, Linkedin, news sources, and archives.

While the development in total revenues is telling of how ports have expanded their overall business, it does not reveal much about the competitive situation in these ports. The reason is that several sources of port revenue are in business areas where there is no private competition. For 
this reason, we focus on revenues from tariffs from ship- and goods-related services. The development of these revenues is presented in Figure 3, which shows tariff revenues of ports in the sample scaled by throughput. Changes in this measure provides a metric of changes in ports' market share of produced services under the simplifying assumption that the composition of services (including the composition of cargo types) has remained relatively constant over the sample period. While our obtained data lacks the richness to directly asses this assumption, official statistics (Statistics Denmark, 2018) do not show any large changes in the composition of traded goods by sea during this time. When the values are segmented by organizational type, we find that there has been an increase in tariff revenues per ton of goods handled by $51 \%$ and $19 \%$ for MOLC and MSG ports respectively. Attempting to construct an appropriate benchmark, we also gather financial data from five large Norwegian and five large Swedish ports. In a sample consisting of the ports of Bergen, Karmsund, Larvik, Oslo, Stavanger, Gothenburg, Helsingborg and Trelleborg, Gavle and Norrkoping, we find that the total revenue per ton of cargo handled is markedly lower than our sample. In the Swedish and Norwegian ports, total revenues per ton of cargo is stable around 4 and 6 euros respectively, while in the Danish sample tariff revenues alone account for 10 euros per ton, and this value is increasing during the post-reform period (as shown in figure 3). In other words, the revenue generated per ton of throughput in Danish ports is at least double that of Norway and Sweden during these years. The total volume growth during the sample period in the Norwegian and Swedish ports is $-1.7 \%$ and the total revenue growth is $0.6 \%$, indicating no dramatic changes in the relative (intra-port) market shares of goods handling or in the composition of services produced. This is a clear contrast to the values presented in Table 4. 
Table 4 - Revenue developments

\begin{tabular}{llccc} 
Port & $\begin{array}{c}\text { Volume } \\
\text { Growth }\end{array}$ & $\begin{array}{c}\text { Volume } \\
\text { CAGR }\end{array}$ & $\begin{array}{c}\text { Revenue } \\
\text { Growth }\end{array}$ & $\begin{array}{c}\text { Revenue } \\
\text { CAGR }\end{array}$ \\
\hline Aarhus (MSG) & $-12,36 \%$ & $-2,17 \%$ & $3,26 \%$ & $0,54 \%$ \\
\hline ADP (MOLC) & $-35,06 \%$ & $-6,94 \%$ & $8,29 \%$ & $1,43 \%$ \\
\hline CMP (MOLC) & $12,99 \%$ & $2,06 \%$ & $11,54 \%$ & $1,84 \%$ \\
\hline Esbjerg (MSG) & $9,25 \%$ & $1,48 \%$ & $47,97 \%$ & $6,75 \%$ \\
\hline Frederikshavn & $-14,22 \%$ & $-2,52 \%$ & $24,96 \%$ & $3,78 \%$ \\
(MSG) & $-2,10 \%$ & $-0,35 \%$ & $24,57 \%$ & $3,73 \%$ \\
\hline Grenaa (MOLC) & $-62.23 \%$ & $-14,98 \%$ & $-4,66 \%$ & $-0,79 \%$ \\
\hline Kalundborg (MSG) & $30,20 \%$ & $4,50 \%$ & $37,32 \%$ & $4,11 \%$ \\
\hline Køge (MSG) & $15,43 \%$ & $2,42 \%$ & $256,95 \%$ & $23,62 \%$ \\
\hline Odense (MOLC) & $11.96 \%$ & $2.29 \%$ & $-10.25 \%$ & $-1.79 \%$ \\
\hline Vejle (MSG) & $\mathbf{- 1 0 , 4 3 \%}$ & $\mathbf{- 1 , 8 2 \%}$ & $\mathbf{3 0 , 2 0 \%}$ & $\mathbf{4 , 5 0 \%}$ \\
\hline Sample total & Source: financial statements $2011-2016$ and Eurostat
\end{tabular}

Figure 3 - Tariff revenues per ton of throughput in Danish ports, compared with Swedish and Norwegian ports.

[Fig 3 here]

Source: Port accounts \& Eurostat (2018b).

Turning to profitability, we find that the average EBIT margin of sampled ports is $26 \%$, and there is very little difference in the average margins of MOLC and MSG ports (24 and $27 \%$ respectively). An average profit margin of $26 \%$ is notably high, though it proves difficult to find an appropriate benchmark. To offer some sense of comparison, a historical average margin of profit for the transportation industry in general is $10 \%$, and the corresponding value for real estate and machineries industries is $21 \%$ and $13 \%$ respectively. Looking again at the group of Norwegian and Swedish ports, EBIT-margins during the same period are $18.9 \%$ on average. The average Swedish port in this group had a margin of $17.2 \%$, while Norwegian ports had a margin of $20.5 \%$. Also notable is that the average profit margin of the Norwegian and Swedish ports has been remarkably stable during 2011-2016, moving only from $19.7 \%$ to $20 \%$. During the same 
period, the profit margins of the Danish sample ports increased from a low of $18 \%$ in 2012 to a high of $30 \%$ in 2016. The Danish sample ports' return on equity, which provides another standard measure of firm profitability, is found to be on average $8.5 \%$ during the period. The group of Norwegian and Swedish ports performed slightly worse with $7.3 \%$.

As shown in table 5, most of the sampled ports have managed to both grow their total assets and their equity, meaning they are both expanding and adding funds. Such a situation is rare in business, as it would attract competition. If ports are able to operate with a privileged competitive position, such expansion may further deter competitor entrants in the future. CMP stands out as noting a growth in total assets but a decline in equity, which is a more expected result for a going concern. As per the writing of this paper, four ports in the sample group are in the process of major expansions with investment costs totalling half a billion Euros. While it is outside the scope of this paper to judge the precise merit of these investments, they occur in a low growth volume market, which does beg the question from which source these investments' return is to come and whether this is an efficient use of public funds.

Table 5: Development of Assets and Equity

\begin{tabular}{ccccc} 
& \multicolumn{2}{c}{ Total Assets } & \multicolumn{2}{c}{ Equity } \\
\hline & Growth & CAGR & Growth & CAGR \\
\hline Aarhus (MSG) & $12.04 \%$ & $1.91 \%$ & $25.13 \%$ & $3.81 \%$ \\
\hline ADP (MOLC) & $2.82 \%$ & $0.46 \%$ & $2.28 \%$ & $0.38 \%$ \\
\hline CMP (MOLC) & $71.85 \%$ & $9.44 \%$ & $-78.00 \%$ & $-22.30 \%$ \\
\hline Esbjerg (MSG) & $68.91 \%$ & $9.13 \%$ & $88.54 \%$ & $11.15 \%$ \\
\hline Frederikshavn (MSG) & $123,95 \%$ & $14,36 \%$ & $-1.61 \%$ & $-0,27 \%$ \\
\hline Grenaa (MOLC) & $-6.85 \%$ & $-1.18 \%$ & $43.13 \%$ & $6.16 \%$ \\
\hline Kalundborg (MSG) & $11,03 \%$ & $1,76 \%$ & $14,96 \%$ & $2,35 \%$ \\
\hline Køge (MSG) & $8.77 \%$ & $1.41 \%$ & $75.50 \%$ & $9.83 \%$ \\
\hline Odense (MOLC) & $181.07 \%$ & $18.80 \%$ & $121.37 \%$ & $14.16 \%$ \\
\hline Vejle (MSG) & $6.89 \%$ & $1.12 \%$ & $7.79 \%$ & $1.26 \%$ \\
\hline Sample total & $\mathbf{2 8 . 5 4 \%}$ & $\mathbf{4 , 2 7 \%}$ & $\mathbf{2 4 , 9 8 \%}$ & $\mathbf{3 , 7 9 \%}$
\end{tabular}

Source: Financial statements 
Finally, we look at the remuneration of CEOs in MSG ports (including Odense, since it was MSG for the entire sample period) to see how this compares to their governing body, the municipality, and general practice. The results are in table 6. It is striking that the wage for port CEOs are on average $65 \%$ higher than their local mayor, who is, ultimately, their superior and in charge of an arguably more complex organization, as well as under more direct democratic control. Precisely what factors warrant such a wage premium for port CEOs is an open question, which is especially interesting as the background of the CEOs in the sample is very diverse. Since they have to give up private sector careers some opportunity cost is likely relevant, but few private sector jobs in Denmark pays above 133000 EUR per year ${ }^{2}$, and likely even fewer in fixed packages, which seems to be the prevailing structure among Port CEOs given the uniformity of the annual numbers. The historical figures make it seem unlikely that the pay packages contain elements of performance pay, and even if they did, how to determine a performance-based reward structure is an outstanding and non- trivial question.

Table 6 - Annual CEO remuneration in MSG ports compared to local mayor - EUR.

\begin{tabular}{|c|c|c|c|c|c|c|c|}
\hline & \multicolumn{5}{|c|}{ Port CEO remuneration } & \multicolumn{2}{|c|}{ Local Mayor Remuneration } \\
\hline & 2012 & 2013 & 2014 & 2015 & 2016 & $\begin{array}{c}\text { Per year } \\
\text { during period }\end{array}$ & $\begin{array}{c}\text { Pay gap: } \\
\text { Mayor - CEO }\end{array}$ \\
\hline Aarhus & 190047 & 211918 & 172952 & 204762 & 209074 & 110125 & -98949 \\
\hline Esbjerg & 188667 & 189600 & 195333 & 197867 & 200933 & 110125 & -90808 \\
\hline Frederikshavn & & & 202622 & 211512 & 223591 & 98387 & -125203 \\
\hline Kalundborg & 122576 & 141733 & 142881 & 144903 & 146310 & 98387 & -47923 \\
\hline Køge & 146056 & 146942 & 148764 & 151020 & 152658 & 98387 & -54271 \\
\hline Odense & 159346 & 159971 & 167600 & 172518 & 175370 & 110125 & -65245 \\
\hline Vejle & & 138267 & 136337 & 122812 & 105657 & 110125 & 4468 \\
\hline
\end{tabular}

\footnotetext{
${ }^{2}$ The average personal income in Denmark is 39840 EUR, and roughly one percent make above 133334 (approximately 1 million DKK).
} 
The findings presented in this section reveal that (1) the management of ports has structurally changed in terms of management competencies, (2) divergence in tariff revenue and volume growth rates suggests that ports are expanding their operations at the expense of private operators, (3) ports have during the sample period been robustly profitable in earnings and return on equity terms. Additionally (4) ports have during the same period been building their balance sheets, while (5) in some cases utilizing the legal structures allowed by the law to optimize shortterm strategy. Finally (6) employment in port management is found to be surprisingly lucrative. These findings are compatible with the explanation that port owners and management have attempted to maximize their outcomes given the institutional structure, and have rather successfully taken advantage of the opportunities granted. The findings pertaining to financial performance essentially indicate that ports are operating with a non-ignorable extent of market power. Whether this was also the case prior to the enactment of the Port Law is outside of this paper's scope to say, but two important facts relating to the monopolistic practices of ports have been documented. The first is that there has been a shift in the stated ambitions of regulators in inducing competition, and the second is that the commercial orientation and competencies of municipally controlled port enterprises has changed. Where port organizations prior to the reform were typified by having a maritime CEO, a political chairman and no department for business development, a more typical picture of the contemporary situation is that ports are managed by a commercially oriented CEO, and an increasing prevalence of business development departments and non-political chairmen. We thus infer that changes have occurred that are attributable to the reform, but an increased tendency for competition or contestability in the service provider market has not materialized.

In his influential analysis of rent distribution in seaports, Goss $(1999$, p. 5) observed that '... those parties interested in retaining their quasi-rents may attack or seek to frustrate any objective 
indicators of efficiency.' We end this segment with the full wording of an email from the chairman of a MSG port to a journalist after an exposé about the port's history of excessive spending: 'I do not know what your aim with soiling the good name of the port is, but try to understand that [name of port] is not (emphasis in original) a municipal port, and therefore does not have access to public funds. The money we spend is earned from our operation. In principle you might as well write about Lego or some other company's travel expenses'. The port in question is an MSG, which is clearly stated in the statues of incorporation. Whether their chairman is ignorant of this status or trying to deceive the journalist is an open question.

\section{Issues with the current framework and beyond}

A few specific concerns can be brought up with regard to the current legal framework governing port practices. The most obvious of these is the apparent weak or non-existent sanctioning of non-compliance with the law. Besides disputes over legal statutes in the law, there is arguably also evidence that the overall intended consequences of the law have not been realized. If the motivation of the law was to incentivize large ports to shift from MSG to MOLC, this begs the question of why expansionary MSG ports have not done so. Studying developing countries, Panayides et al. (2015) found that institutional factors such as regulatory quality and enforcement of contracts are significant determinants of success in port-related public-private partnerships. The lack of rule enforcement in the present case can be hypothesized to deter private investment, much in the same way as corruption or unpredictable regulation can increase the cost of business. This becomes a particularly pressing issue as market disciplinary forces are not in effect. As port service provision is a heavily regulated business, incumbent firms have a lot of stake in future laws and mandates. The interpretive flexibility or incompleteness of certain regulations provides a strategic incentive for stakeholder firms to shape the understanding of the rules so that it 
favours their interests (Funk and Hirschman, 2017). When the allowed and disallowed services under the Port Law are stipulated in such a way that the law becomes open to interpretation, ports can attempt to influence this interpretation and thereby also influence the real impact of the policy by pursuing specific market actions.

An interesting and relevant question is how the Danish experience relates to that of its neighbours in the surrounding greater port region. Are the observable outcomes a consequence of specific policy implemented or are there any common regional trends affecting the path of development? Denmark is most aptly compared with its Scandinavian neighbours. The Norwegian container port system has gone through a process of concentration and then de-concentration (Svindland et al., 2019), which is found to be in line with theoretical predictions of regional port system evolution (Monios, 2017a). Svindland et al. (2019) also find that while small ports have not been rationalised, several stakeholders favour some kind of port reform aimed at centralising port governance within regions. Given that Norway's port governance structure is currently comparable to Denmark, in the sense that much autonomy and control lies with port-owning municipalities, such a policy development could be as divergent from Denmark's chosen path. The Swedish port sector, which is also characterised by municipal involvement and control has undergone partial privatisation in recent years, with large concession deals involving international terminal operating companies being implemented at three significant ports (Bergqvist and Cullinane, 2017). While it is still early to fully evaluate, the process is described as less successful from the point of view of port authorities because of subsequent poor labour relations and increased customer dissatisfaction. This reform process is described as being rather unique in an international context and there are limited parallels to draw with the Danish experience of port reform. It can be stated, however, that the establishment of multinational terminal operating companies and relative shift of influence from port authorities to these is 
largely inconsistent with the observed development in Denmark. The Finnish port industry, which is similarly characterised by municipal governance is another interesting point of comparison. Municipally owned ports in Finland were found to perform poorly in terms of net sales during the years 2002-2009, though the return on assets during the same period was stronger than for instance that of railway and airport owning companies (Leviäkangas et al., 2015). A finding in the Finnish case was that the kind ownership model is not in itself a main driver of infrastructure providers performance. This may serve as a useful reminder that reforms triggering organisational changes are not necessarily sufficient to achieve good outcomes unless the underlying incentive structure is changed in accordance with policymakers objectives. A possible criticism of our review could be that it too narrowly focuses on the short term, and too little on the prolongated effort of the law to set ports free of public control and responsibility. It seems to us that if in fact such a long-term goal is behind the law - which is ultimately a question beyond the ability of our applied methodology to answer, it has it has failed in establishing the policy-relevant goals of the port system. There are many potential benefactors with conflicting interests. The interests of a port's regional economy and employment are not necessarily aligned with the interests of the transport sector as a whole. Commercialization of ports can be broadly thought to imply that mechanisms of the private sector become more pronounced in port service provision. This would ideally mean that commercialized ports are more responsive to customer demand, and are more able to produce services in a cost-efficient manner. If this were the intention of policy makers, it is unclear why the law ultimately leaves deciding the degree of commercialization to the municipalities. The management of conflicting benefactor interests in ports requires at the very least some degree of national coordination in determining overall goals and objectives. The lack of clear priorities and coordination is a potential explanation for poor general welfare performance of the port sector. Talk of cooperation or competition is hollow if it 
is unclear who to compete against and who to cooperate with. With this in mind, we find it relevant to address in discussing future legislation the desired role of municipalities in port ownership and management. The matter is complex; without a profitable port, some municipalities might for instance prioritize housing rather than port activities on the seaside. There is also the matter of financing. Just as taxpayers are ultimately stuck with the bill for inefficiently allocated investments, or malinvestments, in ports, the nature of municipal credits is such that other municipal financing needs, schools, kindergartens etc., may become more expensive without the port assets.

Finally, one could question whether the desired relationship between operational freedom and scale, which is implied by the Port Law, is not in fact backwards. The higher the scale of commercial port operations, the more a port is expected to be organized in such a way that it is independent from its public owners. The operational freedoms granted to MSG and MOLC ports can be described as the freedom to 'fill in the gaps' left open by the market. However such gaps, to the extent that they exist, are presumably smaller the larger the scale of operations. This reflects the somewhat paradoxical nature of the Port Law; the problem of service provision is seemingly considered more likely to be handled by the market in small than in large ports.

\section{Conclusions}

In the same section referenced in the introduction, Smith ([1776] 1976) writes that the 'abuses which sometimes creep into the local administration' are relatively 'easily corrected'. We have demonstrated that Danish ports have been characterized for the past years by divergent growth rates in revenues and volumes, coupled with substantial expansionary developments, while maintaining robust rates of profitability. We have argued that these facts, combined with the current set of formal rules provided by the Port Law, are suggestive evidence of unchecked and 
successful rent seeking by port owners and management. In order to fully realize benefits of trade in a small and open economy, it appears especially important that economic surpluses are not unduly intercepted by any agent in ports. A concrete suggestion, which is in line with SuarezAleman et al. (2018) is that the regulatory framework for ensuring a competitive port sector should include not only well-intentioned legal reforms to stimulate competition, but also mechanisms for monitoring and sanctioning anti-competitive actions. This is in order to reduce the room for anti-competitive behaviour in the market. We consider this a major lesson to be learned from the present case. Active monitoring and implementing legal adjustments in response to adverse outcomes ought to be a key part of this regulatory effort. Whether issues of market power are 'easily corrected' is ultimately for policy makers to prove. A few recommendations can however be suggested.

i) It appears essential in regulating the ability for public ports to compete with private operators that there be viable forms of sanctioning non-compliance. Given sufficient and credible sanctioning measures, monopolistic practices in port operations may be successfully deterred.

ii) The extent and impact of inherited institutional privileges (the so-called grandfather rights) ought to be carefully evaluated. If it is the belief of policy makers that the legal framework can successfully regulate public-private competition, it is difficult to see why there should be a large number of exceptions to the rule.

iii) The connection between ports' operational scale and legally granted freedom to 'fill in the gaps' in service provision should be reconsidered. There is likely to be more room for private service provision the larger the scale of port operations, ceteris paribus.

All things considered, there is little evidence that the Port Law has aided a development toward the cost efficient production of goods handling services. Nor has it established a stable 
institutional environment in which private operators can compete on fair terms. To what extent the documented changes triggered by the reform will impact Danish ports' competitiveness in the greater Scandinavia/Baltic area is an interesting question deserving of further analysis. We have seen that the Scandinavian models of port governance, while similar in many regards, may be on the cusp of diverging. The interrelationship in port development between these countries is another topic that can be suggested for future research. Danish port governance does not stand out as a supportive case for the popular notion of Nordic exceptionalism in public administration, whatever merit such a claim might have in other areas. Agents working in Danish ports have, as we in any setting expect economic agents to do, maximized their utility with speed and efficiency.

\section{References}

Baird, A. J. (2000). Port privatisation: objectives, extent, process, and the UK experience. International Journal of Maritime Economics, 2(3), 177-194.

Baird, A. J., \& Valentine, V. F. (2006). Port privatisation in the United Kingdom. Research in Transportation Economics, 17, 55-84.

Bergqvist, R., \& Cullinane, K. (2017). Port privatisation in Sweden: Domestic realism in the face of global hype. Research in Transportation Business \& Management, 22, 224-231.

Brooks, M. R. (2004). The governance structure of ports. Review of Network Economics, 3(2).

Brooks, M. R., Cullinane, K. P., \& Pallis, A. A. (2017). Revisiting port governance and port reform: A multi-country examination. Research in Transportation Business \& Management, (22), 1-10.

Brooks, M. R., \& Pallis, A. A. (2012). Port governance. In: The Blackwell Companion to Maritime Economics, 491-516.

Buchanan, J.M. and Tullock, G., 1962. The calculus of consent (Vol. 3). Ann Arbor: University of Michigan Press. 
Castillo-Manzano, J. I., Castro-Nuño, M., González-Laxe, F., \& Pedregal, D. J. (2018). Legal reform and the devolution of the Spanish Port System: An econometric assessment. Utilities Policy, 50, 73-82.de

De Langen, P. W., \& Pallis, A. A. (2006). Analysis of the benefits of intra-port competition. International Journal of Transport Economics/Rivista internazionale di economia dei trasporti, 69-85.

De Langen, P. W., \& Pallis, A. A. (2007). Entry barriers in seaports. Maritime Policy \& Management, 34(5), 427-440.

Debrie, J., Gouvernal, E., \& Slack, B. (2007). Port devolution revisited: the case of regional ports and the role of lower tier governments. Journal of Transport Geography, 15(6), 455-464.

Debrie, J., Lavaud-Letilleul, V., \& Parola, F. (2013). Shaping port governance: the territorial trajectories of reform. Journal of Transport Geography, 27, 56-65.

Debrie, J., Lacoste, R., \& Magnan, M. (2017). From national reforms to local compromises: The evolution of France's model for port management, 2004-2015. Research in Transportation Business \& Management, 22, 114-122.

European Union (2017). Establishing a framework for the provision of port services and common rules on the financial transparency of ports. Official Journal of the European Union L57, $1-18$.

Eurostat, (2018a), "Population change - Demographic balance and crude rates at national level", available at: http://appsso.eurostat.ec.europa.eu/nui/show.do?dataset=demo_gind\&lang=en (accessed 22 February 2018)

Eurostat, (2018b), "Gross weight of goods handled in all ports by direction - annual data”, available at: http://appsso.eurostat.ec.europa.eu/nui/show.do?dataset=mar_go_aa\&lang=en (accessed 22 February 2018)

Estache, A., \& Fay, M. (2007). Current debates on infrastructure policy. Policy Research Working Paper. The World Bank.

Funk, R. J., \& Hirschman, D. (2017). Beyond nonmarket strategy: Market actions as corporate political activity. Academy of Management Review, 42(1), 32-52. 
Goss, R. O. (1990a). Economic policies and seaports: Are port authorities necessary?. Maritime Policy \& Management, 17(4), 257-271.

Goss, R. O. (1990b). Economic policies and seaports: The diversity of port policies. Maritime Policy \& Management, 17(3), 221-234.

Goss, R. O. (1990c). Economic policies and seaports: The economic functions of seaports. Maritime Policy \& Management, 17(3), 207-219.

Goss, R. O. (1999). On the distribution of economic rent in seaports. International Journal of Maritime Economics, 1(1), 1-9.

Havnelovudvalget (2011). Betænkning om havneloven. Available at: https://www.trm.dk/da/publikationer/2011/betaenkning-om-havneloven

Hitt, M.A., Ireland, R.D. (1985): Corporate distinctive competences, strategy, industry and performance, Strategic Management Journal. 6 (3), 273-293.

Hrebiniak, L.G., Snow, C.G. (1982) Top management agreement and organizational performance. Human Relations 35 (12) (1982).

KL (2016) Overenskomst for maritimt personale (Maritime Staff Agreement). Available at: https://www.kl.dk/ImageVaultFiles/id_32814/cf_202/42.PDF

Krueger, A. O. (1974). The political economy of the rent-seeking society. The American economic review, 64(3), 291-303.

Learned, E. P., Christensen, C. R., Andrews, K. R., \& Guth, W. D. (1969). Business policy: Text and cases. Homewood, IL: RD Irwin.

Leviäkangas, P. J., Nokkala, M. J. M., \& Talvitie, A. P. (2015). A slice or the whole cake? Network ownership, governance and public-private partnerships in Finland. Research in Transportation Economics, 49, 2-13.

Lovbekendtgoerelse (LBKG) nr. 457, 23.05.2012 [The Port Law].

Marques, R. C., \& Fonseca, Á. (2010). Market structure, privatisation and regulation of Portuguese seaports. Maritime Policy \& Management, 37(2), 145-161.

Monios, J. (2017a). Cascading feeder vessels and the rationalisation of small container ports. Journal of Transport Geography, 59, 88-99.

Monios, J. (2017b). Port governance in the UK: Planning without policy. Research in Transportation Business \& Management, 22, 78-88. 
Ng, A. K., \& Pallis, A. A. (2010). Port governance reforms in diversified institutional frameworks: generic solutions, implementation asymmetries. Environment and Planning A, 42(9), 2147-2167.

Notteboom, T., De Langen, P., \& Jacobs, W. (2013). Institutional plasticity and path dependence in seaports: interactions between institutions, port governance reforms and port authority routines. Journal of Transport Geography, 27, 26-35.

Pallis, A. A. (2006). EU port policy: Implications for port governance in Europe. Research in Transportation Economics, 17, 479-495.

Pallis, A. A. (2007). Whither port strategy? Theory and practice in conflict. Research in Transportation Economics, 21, 343-382.

Pallis, A. A., \& Vaggelas, G. K. (2017). A Greek prototype of port governance. Research in transportation business \& management, 22, 49-57.

Parola, F., Ferrari, C., Tei, A., Satta, G., \& Musso, E. (2017). Dealing with multi-scalar embeddedness and institutional divergence: Evidence from the renovation of Italian port governance. Research in Transportation Business \& Management, 22, 89-99.

Panayides, P. M., Parola, F., \& Lam, J. S. L. (2015). The effect of institutional factors on publicprivate partnership success in ports. Transportation Research Part A: Policy and Practice, 71, 110-127.

Smith, A. ([1776] 1976). An Inquiry into the Causes and Nature of the Wealth of Nations, Book V Part III Article 1, University of Chicago Press, Chicago, IL.

Statistics Denmark, (2018), "Throughput of goods in major Danish seaport by direction, seaport, type of goods and time", available at: http://www.statbank.dk/statbank5a/default.asp?w=1920 (accessed 22 February 2018)e equal?. Transportation Research Part A: Policy and Practice, 86, 56-77.

Suárez-Alemán, A., Serebrisky, T., \& Ponce De León, O. (2018). Port competition in Latin America and the Caribbean: the role of concessions and competition policy. Maritime Policy \& Management, 45(5), 665-683.

Svindland, M., Monios, J., \& Hjelle, H. M. (2019). Port rationalization and the evolution of regional port systems: the case of Norway. Maritime Policy \& Management, 1-17.

Søndergaard, P. \& Kaarøe, I. (2017, July 24). Shippingtopchef: Kommune stjæler opgaver. Bфrsen. 
Tongzon, J., \& Heng, W. (2005). Port privatization, efficiency and competitiveness: Some empirical evidence from container ports (terminals). Transportation Research Part A: Policy and Practice, 39(5), 405-424.

Transport- og Energiministeriet (2007). Danske havne til fremtidens transportløsninger - Dansk havnestrategi 2025. Available at link: https://www.trm.dk/da/publikationer/2007/danskehavne-til-fremtidens-transportloesninger---dansk-havnestrategi-2025

Gonzales, M. M. \& Trujillo, L. (2008). Reforms and infrastructure efficiency in Spain's container ports. Transportation Research Part A: Policy and Practice, 42(1), 243-257.

Valleri, M. A., Lamonarca, M., \& Papa, P. (2006). Port governance in Italy. Research in Transportation Economics, 17, 139-153.

Van Reeven, P. (2010). The effect of competition on economic rents in seaports. Journal of Transport Economics and Policy (JTEP), 44(1), 79-92.

World Bank (2007). Port Reform Toolkit. Second Edition. http://siteresources.worldbank.org/INTPRAL/Resources/338897-

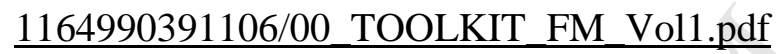





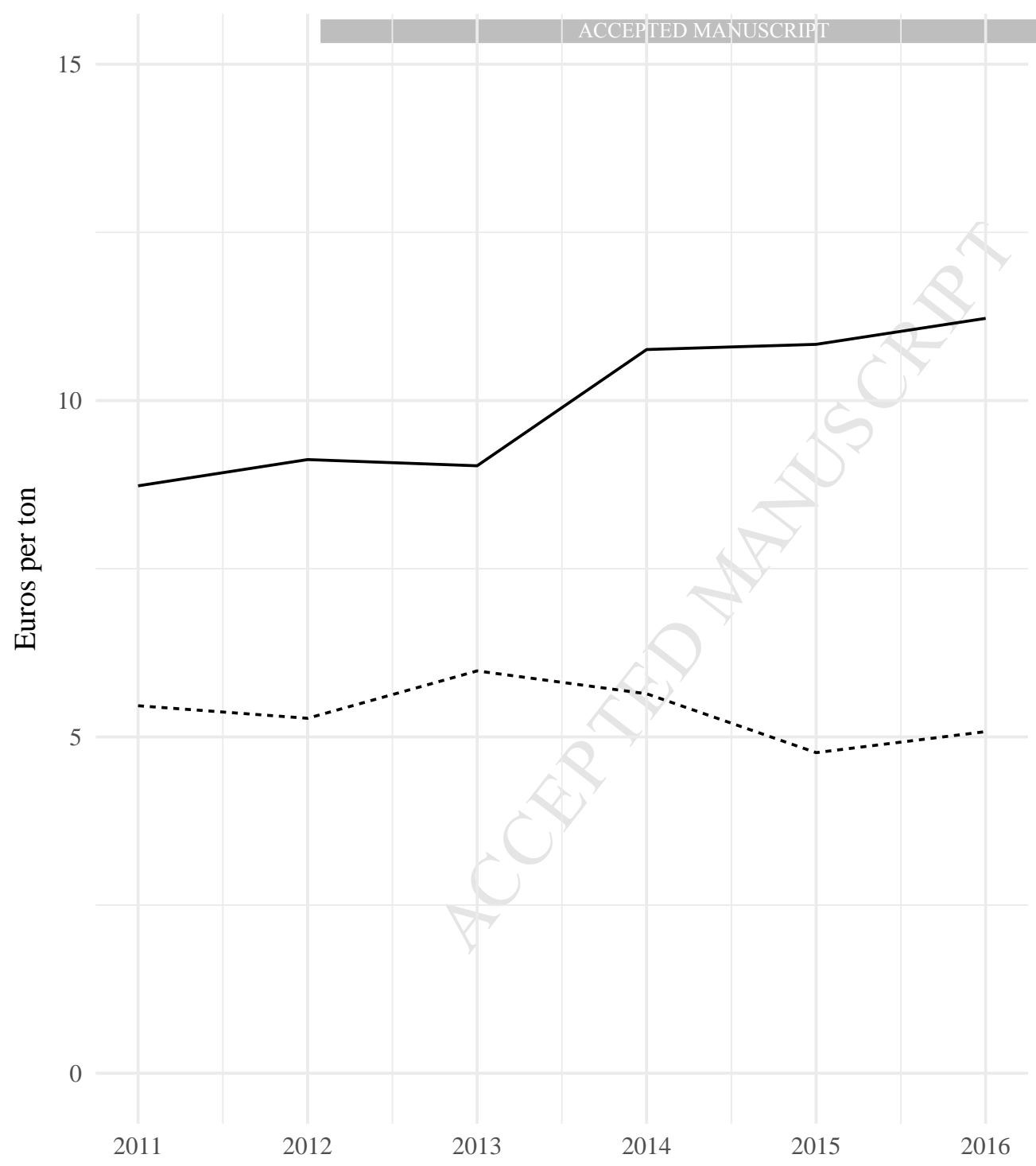

— Tariff revenues DK

-..- Total revenues NO \& SE 


\section{Highlights}

- Overview of the recent regulatory reform governing the Danish port sector.

- Documents the resulting changes to the structure of management, the financial strength and the market power of partially or fully municipally controlled ports.

- The institutional arrangement documented enabled an expansionary development of municipally controlled ports despite a period of overall slowdown in goods volumes.

- The paper mainly engages the need for port reform to address and manage opportunistic behaviour. 